\title{
SYNOVECTOMY FOR RHEUMATOID ARTHRITIS
}

\author{
M. C. WILKINSON, RAMSEY, ISLE OF MAN \\ and \\ J. H. LOWRY, LONDONDERRY, NORTHERN IRELAND \\ From the Black Notley Hospital, Essex, England
}

In the year 1900 synovectomy, both for tuberculosis and for rheumatoid arthritis, was discussed at a meeting of the Sociéte de Chirurgie de Paris (Mignon 1900) and the point was made that the operation was an arthrotomy or partial synovectomy, rather than a total synovectomy. Fisher (1929) claimed good results from arthrotomy and lavage of rheumatoid joints. In 1929 Allison and Coonse reported that 95 per cent of their patients with nontuberculous arthritis treated by synovectomy were relieved of pain; that the range of movement after operation was about the same as before; and that the average duration of treatment was about six months. Jones (1923) advised early movement after synovectomy, and Steindler (1925) favoured the removal of "obnoxious tissues" from joints and said that this was best done when the disease had become quiescent. Swett $(1938,1950)$ advocated synovectomy for non-tuberculous arthritis, and after the introduction of anti-tuberculous drugs he also recommended it for tuberculous joints. More recently London (1955) advocated synovectomy for the treatment of rheumatoid joints and the value of this method of treatment has been reaffirmed by Bastow (1964).

This article reports a study of the effects of synovectomy in the treatment of patients with rheumatoid arthritis, in whom the disease was well advanced. Only the most severely affected joints were selected for this operation. The average duration of symptoms was eight and a half years. In the knee the operation involved removal of the anterior half of the synovial membrane, including the suprapatellar pouch and sometimes the same amount of the capsule. In the less advanced stages of the disease the synovial membrane was found to be swollen and turgid and distinct from the capsule. In the more advanced stages it was fibrosed, contracted and adherent to the capsule. Frayed and battered menisci and necrosed and flaking portions of articular cartilage were removed. Pannus was often present, either young and soft or old and leathery, and also needed to be removed. The joints were often full of fibrinous material containing calcified plaques. The patella was removed if there was damage to its cartilage.

\section{MATERIAL}

Our patients were treated by a period of constitutional treatment and splintage before synovectomy. This method was adopted for selected patients as the result of a trial conducted in the open air wards of Black Notley Hospital with the cooperation and guidance of Dr W. S. Tegner and Dr R. M. Mason of the London Hospital, the results of which have been reported (Mason and Wenley 1959). Forty patients were treated by rest, splintage and analgesics, and thirteen of them underwent synovectomy. Mason and Wenley reported that, in these forty patients, function had been improved; the activity of the disease lessened; and that the method of treatment was worthy of extension. It was observed that patients with polyarthritis, even of long duration, improved with only rest and splintage for six weeks; that many joints in which the disease was chiefly synovial settled down without surgery; that pain and muscular spasm persisted in some of the worse joints and that in these material benefit followed synovectomy. Of the thirteen patients mentioned, it was reported that on admission five of the patients were in grade 3 and eight in grade 4; and that on discharge one patient was in grade 2 , ten in grade 3 and only two remained in grade 4. 
Since this trial an additional forty-nine patients have been treated by combined constitutional therapy and synovectomy, making a total of sixty-two patients treated. Some of these patients had operations on more than one joint, making a total of 103 joints. There were five children in the series and one girl of sixteen; the remainder were adult. In four patients the disease was monarticular. In every patient the diagnosis was confirmed either by

TABLE I

Early Results of Synovectomy in Sixty-nine Joints in which Function was Present on Discharge of the Patient from Hospital

\begin{tabular}{|c|c|c|c|}
\hline Joint & $\begin{array}{l}\text { Number of } \\
\text { joints affected }\end{array}$ & $\begin{array}{c}\text { Pain } \\
\text { relieved }\end{array}$ & $\begin{array}{c}\text { Pain } \\
\text { unrelieved }\end{array}$ \\
\hline Hip & 1 & 1 & 0 \\
\hline Knee & 43 & 42 & 1 \\
\hline Ankle & 2 & 2 & 0 \\
\hline Shoulder & 1 & 1 & 0 \\
\hline Elbow & 4 & 3 & 1 \\
\hline Wrist & 6 & 6 & 0 \\
\hline Metacarpo-phalangeal & 10 & 10 & 0 \\
\hline Interphalangeal & 2 & 2 & 0 \\
\hline Total & 69 & 67 & 2 \\
\hline
\end{tabular}

TABLE II

Early Results of Synovectomy in ThiRty-four Joints Which Were Stiff or Nearly Stiff at the Time of the Patient’s Discharge

\begin{tabular}{|c|c|c|c|c|c|}
\hline \multicolumn{3}{|c|}{ Joint } & $\begin{array}{l}\text { Number of } \\
\text { joints affected }\end{array}$ & $\begin{array}{c}\text { Pain } \\
\text { relieved }\end{array}$ & $\begin{array}{c}\text { Pain } \\
\text { unrelieved }\end{array}$ \\
\hline Hip. & . & . & 1 & 1 & 0 \\
\hline Knee & . & . & 9 & 7 & 2 \\
\hline Ankle & . & . & 1 & 1 & 0 \\
\hline Shoulder & & . & 0 & 0 & 0 \\
\hline Elbow & $\cdot$ & . & 3 & 2 & 1 \\
\hline Wrist & . & . & 9 & 9 & 0 \\
\hline Metacar & po-ph & alangeal & 4 & 4 & 0 \\
\hline Interpha & langea & 1 & 7 & 5 & 2 \\
\hline & otal & . & 34 & 29 & 5 \\
\hline
\end{tabular}

histology or a positive Rose test; in many patients both investigations were positive. The average duration of follow-up was three years and eight months. The follow-up reports were obtained either by examination by us, a report from their doctor, or from a questionnaire filled in by the patient. Information was not received about eight patients who had had twelve operations.

vol. 47 B, No. 3, AUGUST 1965 


\section{RESULTS}

Table I and Table II show that ninety-six out of 103 joints ( 93 per cent) were comfortable at the time of the patients' discharge and seven ( 7 per cent) were painful. Sixty-seven out of sixty-nine of the mobile joints were relieved of pain ( 97 per cent), as were twenty-nine out of

TABLE III

Later Results of Synovectomy in Sixty-one out of Sixty-nine Joints Mobile on Discharge from Hospital Average duration of follow-up: three years eight months

\begin{tabular}{|c|c|c|c|c|c|c|c|c|}
\hline \multicolumn{3}{|c|}{ Joint } & \multirow{2}{*}{$\begin{array}{c}\begin{array}{c}\text { Number } \\
\text { discharged } \\
\text { mobile }\end{array} \\
1\end{array}$} & \multirow{2}{*}{$\begin{array}{c}\begin{array}{c}\text { Number } \\
\text { followed } \\
\text { up }\end{array} \\
1\end{array}$} & \multirow{2}{*}{$\frac{\begin{array}{c}\text { Function } \\
\text { maintained }\end{array}}{1}$} & \multirow{2}{*}{$\frac{\begin{array}{c}\text { Function } \\
\text { lost }\end{array}}{0}$} & \multirow{2}{*}{$\begin{array}{c}\begin{array}{c}\text { Pain } \\
\text { relieved }\end{array} \\
1\end{array}$} & \multirow{2}{*}{$\begin{array}{c}\begin{array}{c}\text { Pain } \\
\text { unrelieved }\end{array} \\
0\end{array}$} \\
\hline Hip. & . & . & & & & & & \\
\hline Knee & . & . & 43 & 35 & 30 & 5 & 28 & 7 \\
\hline Ankle & . & . & 2 & 2 & 1 & 1 & 1 & 1 \\
\hline Shoulder & . & . & 1 & 1 & 1 & 0 & 1 & 0 \\
\hline Elbow & . & . & 4 & 4 & 3 & 1 & 3 & 1 \\
\hline Wrist & . & . & 6 & 6 & 3 & 3 & 5 & 1 \\
\hline Metacar & po-pha & langeal & 10 & 10 & 8 & 2 & 10 & 0 \\
\hline Interphal & langea & . & 2 & 2 & 2 & 0 & 2 & 0 \\
\hline & otal & . & 69 & 61 & 49 & 12 & 51 & 10 \\
\hline
\end{tabular}

TABLE IV

Follow-up of Thirty out of Thirty-four JoINTs Stiff OR Nearly Stiff on Discharge from Hospital Average duration of follow-up: three years eight months

\begin{tabular}{|c|c|c|c|c|c|c|c|c|}
\hline \multicolumn{4}{|c|}{ Joints } & \multirow{2}{*}{$\frac{\begin{array}{c}\text { Number } \\
\text { discharged stifi }\end{array}}{1}$} & \multirow{2}{*}{$\frac{\begin{array}{c}\text { Number } \\
\text { followed up }\end{array}}{1}$} & \multirow{2}{*}{$\begin{array}{c}\begin{array}{c}\text { Stifiness } \\
\text { maintained }\end{array} \\
1\end{array}$} & \multirow{2}{*}{$\begin{array}{c}\begin{array}{c}\text { Pain } \\
\text { relieved }\end{array} \\
1\end{array}$} & \multirow{2}{*}{$\begin{array}{c}\begin{array}{c}\text { Pain } \\
\text { unrelieved }\end{array} \\
0\end{array}$} \\
\hline Hip. & . & . & . & & & & & \\
\hline Knee & . & . & . & 9 & 6 & 6 & 4 & 2 \\
\hline Ankle & . & . & . & 1 & 1 & 1 & 1 & 0 \\
\hline Shoulder & . & . & . & 0 & 0 & 0 & 0 & 0 \\
\hline Elbow & . & . & . & 3 & 3 & 3 & 2 & 1 \\
\hline Wrist & . & 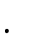 & . & 9 & 8 & 8 & 7 & 1 \\
\hline Metacar & o-pha & lang & & 4 & 4 & 4 & 4 & 0 \\
\hline Interpha & angea & & . & 7 & 7 & 7 & 3 & 4 \\
\hline & tal & . & . & 34 & 30 & 30 & 22 & 8 \\
\hline
\end{tabular}

thirty-four of the stiff joints ( 85 per cent). Twenty-four out of the thirty-four stiff or nearly stiff joints were severely affected before the operation.

Table III shows that patients with sixty-one joints out of sixty-nine which were mobile at the time of discharge were followed up. Forty-nine out of sixty-one ( 80 per cent) kept their mobility and twelve ( 20 per cent) had become stiff. Fifty-one joints ( 84 per cent) had remained comfortable, and ten ( 16 per cent) were painful. Two of these were in in-patients whose joints were painful at the time of discharge. 
Table IV shows that thirty of the thirty-four joints which were stiff on discharge from hospital were followed up and that they all remained stiff. Twenty-two ( 73 per cent) remained comfortable; eight ( 26 per cent) including five which were painful on discharge from hospital stayed painful.

Table $\mathrm{V}$ shows the relative but not the total incidence of pain (as in Table III) found at follow-up in mobile joints and in stiff joints. Results of the treatment of patients rather than joints were also considered. The average duration of treatment of the sixty-two patients in the series was seven months.

Table VI shows an approximate estimate of their activity, and also the activity of the rheumatoid arthritis. Seven of these patients had been readmitted for further treatment.

TABLE V

Follow-up of Ninety-one Joints to Show Relative InCIDEnCE of Pain in Mobile and Stiff Joints

\begin{tabular}{|lccc}
\hline & $\begin{array}{c}\text { Number of } \\
\text { joints }\end{array}$ & $\begin{array}{c}\text { Pain } \\
\text { relieved }\end{array}$ & $\begin{array}{c}\text { Pain } \\
\text { present }\end{array}$ \\
\hline Mobile & 49 & 46 & 3 \\
\hline Stiff . & $\frac{42}{27}$ & $\frac{27}{73}$ & 15 \\
\hline Total . & 91 & 18 \\
\hline
\end{tabular}

TABLE VI

The Approximate Effect of Constitutional Treatment, Splintage and Synovectomy on Sixty-two Patients

\begin{tabular}{|c|c|c|}
\hline & $\begin{array}{l}\text { Immediate results } \\
\text { (62 patients) }\end{array}$ & $\begin{array}{c}\text { Follow-up results } \\
\text { (54 patients) }\end{array}$ \\
\hline Unassisted activity & 48 & 39 \\
\hline Considerable limitation of activity & 14 & 15 \\
\hline Rheumatoid arthritis quiescent & 49 & 37 \\
\hline Rheumatoid arthritis persistent & 13 & 17 \\
\hline
\end{tabular}

\section{COMMENT}

Hip-Only two patients had synovectomy of the hip without any other operative treatment. The joint causing greatest distress was always selected for operation and, in this series, this was seldom the hip.

Knee-Of the thirty patients who on follow-up were reported to have moveable knees, a record of the range of movement was available in twenty-seven. The range averaged 60 degrees from full extension. Several technical points which are important if function is to be preserved should be mentioned. First, some control of the inflammatory process should be established by rest and splintage before operation; the usual duration in this series was six weeks. Second, complete haemostasis must be obtained at operation after removal of the tourniquet. Third, the patients were nursed with the knee on a Thomas's bed splint without rigid immobility; quadriceps drill was started within a day or two and active flexion and extension exercises within a week

vol. 47 B, NO. 3, AUGUST 1965 
or two. Care was taken to preserve the cruciate and the lateral ligaments at operation, so that instability did not occur.

Ankle-Access to the three joints operated on was by an antero-lateral incision, which gave only a limited view, but relief of pain was obtained in all three and a useful range of movement in two of them.

Shoulder--Only one shoulder was treated by synovectomy; the patient regained complete comfort and almost a full range of movement.

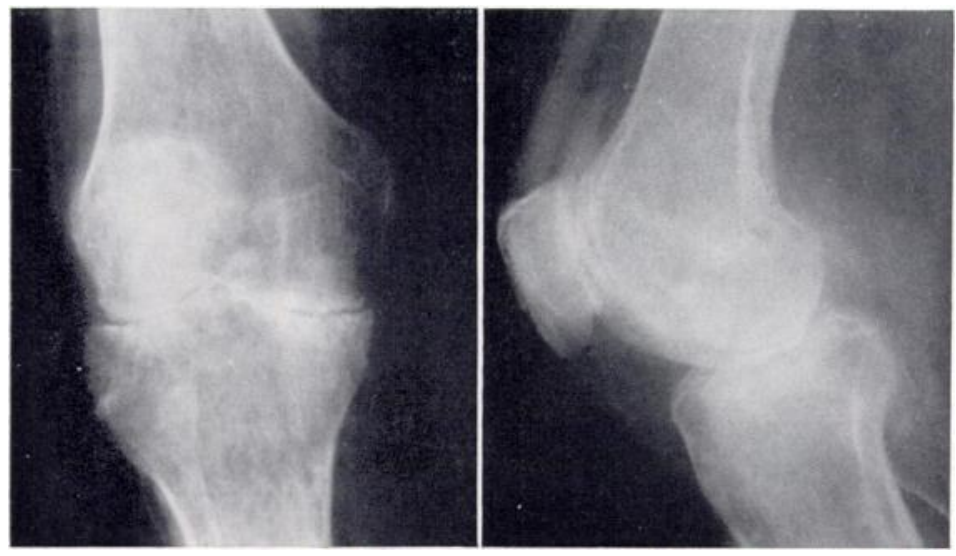

Fig. 1

Antero-posterior and lateral radiographs of the right knee of a woman of 50 years with an eleven years' history of progressive polyarthritis, before synovectomy.
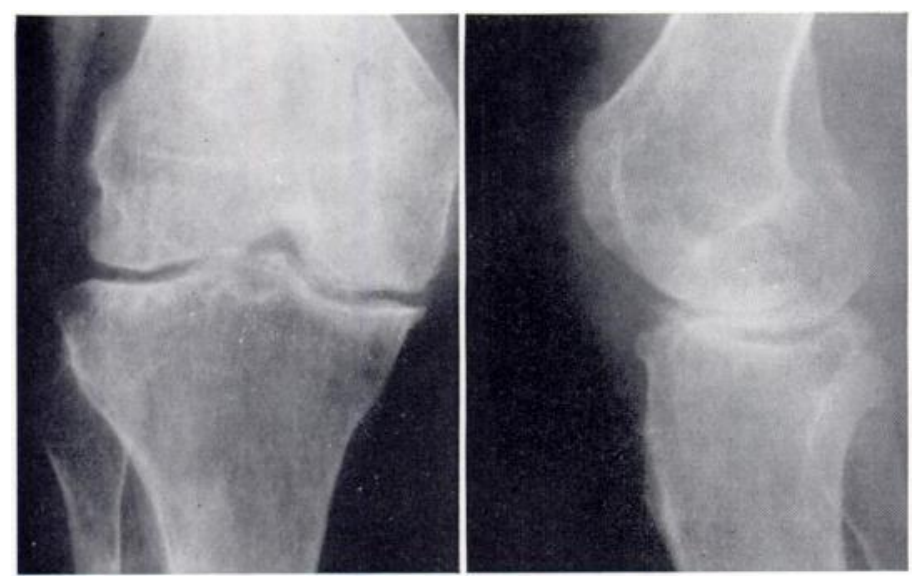

FIG. 2

Radiographs of the same knee two and a half years later.

Elbow-A useful range of movement was more difficult to obtain as the trochlear articular surface of the humerus sinks deeper into the greater sigmoid cavity of the ulna which is enlarged as a result of the disease, with the result that the anterior border of the coronoid process rides against the front of the humerus when an attempt is made to flex the elbow beyond a right angle. It might be an advantage to remove part of the anterior lip of the coronoid.

Wrist-In the fifteen patients reported, synovectomy of the wrist joint was combined with release of all the extensor tendons running under the extensor retinaculum. Sometimes these 
tendons were found to be so tightly gripped by the fibrosed retinaculum that they were marked by a circular constriction; at other times the tendons were found to be surrounded by rheumatoid granulation tissue. Rheumatoid disease of the tendons was seen in only one patient. Attrition effects were not seen.

An interesting observation was that after tendon release from the tight retinaculum, ulnar adduction of the fingers was immediately improved. Unfortunately it tended to recur as the wound healed, and was no doubt due to relief of tension on the tendon which helps to drag it down on the ulnar side of the metacarpo-phalangeal joint. Synovectomy of the wrist also included the carpal joints and removal of bony roughness and projections.

Metacarpo-phalangeal joints-These joints responded well to synovectomy. The operations were performed without a tourniquet and under a local anaesthetic, which is adequate unless removal of osteophytes is required, when a brachial block is preferable. Each joint was approached along its postero-medial aspect, a route free from risk to important structures, except possibly the dorsal interosseous tendon (Last 1956). The tendinous expansion was never found to be adherent and could be retracted sufficiently to see the outer side of the joint. The intra-articular tension was often great and the synovial membrane ballooned out.

Interphalangeal joints-Pain was relieved in the nine joints operated on but there was little success in restoring function.

\section{DISCUSSION}

Following synovectomy for rheumatoid arthritis, new synovial tissue is formed, capable of the dialysis of synovial fluid. To some extent nutrition of cartilage is restored and the removal of necrosed tissue favours revascularisation. That the benefits are not merely symptomatic is seen not only from the return to near normal function of many joints but also from the improved radiological appearance which is sometimes seen (Figs. 1 and 2). It should be added that good joint function may be present and the joint may be comfortable though the radiological appearance is unaltered.

Five patients, with seven joints operated upon, are known to have had steroid therapy in the interval between their discharge from hospital and their last follow-up examination. Only one of these joints which was in a very favourable condition is included in the follow-up tables as a comfortable joint with maintenance of function. Four joints are classified as stiff on follow-up and five as painful. No other joint in a patient known to have had steroid treatment in the interval between discharge and follow-up is classified as being both comfortable and mobile.

\section{SUMMARY}

1. The follow-up reports of ninety-one joints affected by rheumatoid arthritis and treated by synovectomy showed that seventy-three joints remained free of pain. Forty-nine out of ninety-one joints retained useful function after a period averaging three and a half years.

2. The average duration of the disease before admission was eight and a half years.

3. The joints causing most distress were selected for operation. Better results might have been obtained if these patients had received constitutional treatment, splintage and synovectomy earlier. Many of these patients had advanced disease which was continuing to advance at the time of their admission, in spite of previous treatment. Many accepted a trial of treatment in a long stay hospital as a last hope.

4. The return of forty-eight out of sixty-two patients to unassisted or nearly unassisted activity and the maintenance of this state in thirty-nine out of fifty-four shows that the success of the pilot scheme conducted in cooperation with Dr W. S. Tegner and Dr R. M. Mason of the London Hospital has been confirmed by further experience.

We would like to thank Dr W. S. Tegner and Dr R. M. Mason for their advice and encouragement, and also the Medical Research Council, who have assisted the follow-up work by means of a grant.

Vol. 47 B, No. 3, AUGUST 1965 


\section{REFERENCES}

Allison, N., and Coonse, G. K. (1929): Synovectomy in Chronic Arthritis. Archives of Surgery, 18, 824.

Bastow, J. (1964): Symposium on Rheumatoid Arthritis. Proceedings of the Royal Society of Medicine (Section of Orthopaedics), 57, 65.

Fisher, A. G. Timbrell (1929): Chronic Non-tuberculous Arthritis. London: H. K. Lewis and Co.

JoNeS, E. (1923): Synovectomy of the Knee Joint in Chronic Arthritis. Journal of the American Medical Association, 81, 1579.

LAST, R. J. (1956): Personal communication.

London, P. S. (1955): Synovectomy of the Knee in Rheumatoid Arthritis. Journal of Bone and Joint Surgery, 37-B, 392.

Mason, R. M., and Wenley, W. G. (1959): Treatment of Rheumatoid Arthritis by a Sanatorium Régime. Annals of the Rheumatic Diseases, 18, 91.

Mignon, A. (1900): Synovectomie du genou. Bulletins et Mémoires de la Société de Chirurgie de Paris, 26, 1113.

Steindler, A. (1925): Synovectomy and Fat Pad Removal in the Knee. Journal of the American Medical Association, 84, 16.

SwetT, P. P. (1938): A Review of Synovectomy Journal of Bone and Joint Surgery, 20, 68.

SWETt, P. P. (1950): Personal communication. 